\title{
An Error Analysis on The Students' Writing of Recount Text
}

\author{
Tri Septiana Ningsih, Siswantoro, Martono
}

\author{
English Education Department \\ Teacher Training and Education Faculty \\ Sebelas Maret University of Surakarta
}

Email: septiana37@gmail.com

\begin{abstract}
The aims of this research are: (1) to find out the type of error of a recount text made by the eighth grade students of SMP N in Surakarta; (2) to find out the highest percentage of type of the students errors; (3) to find out the causes of the studentse errors. This research is descriptive. To collect the data, the researcher uses an essay test in the form of recount text composition made by the eighth grade students. The sample of the research is 24 students of class VIII A. To categorize the type of error, the researcher uses surface strategy taxonomy. The results of this research are: (1) there are four types of errors yielded by the students which are addition error (14.34\%), omission error (29.81\%), misformation error $(55.10 \%)$ and misordering error $(0.75 \%)$; (2) the highest percentage of type of errors is misformation error with the percentage of $(55.10 \%)$; (3) there are two causes of errors found from the students ${ }^{\text {ee }}$ writing which are interlingual error with the percentage of $58.49 \%$ and intralingual error $(41.51 \%)$.
\end{abstract}

\section{Keywords: Error Analysis, Surface Strategy Taxonomy, Recount text}

\section{INTRODUCTION}

English as a second language has been taught for years in Indonesia. It is taught obligatorily in Indonesia at the level of junior high school. Learning English as a second language always takes time. Junior high school students who are studying English as their compulsory subject may face difficulties during their learning process. English has different structures from Indonesian which makes the students difficult to understand. Some differences between English and Indonesian lead the students to making mistakes and errors.

As the first language learned and acquired by the students, Indonesian structure sometimes interfere the students when it is applied to the target language structures. The example of this case is „Last night, I and my friend went to Risa* house', that sentence needs a possessive marker ,- $\mathrm{S}^{\text {ee }}$ besides the noun Risa. This rule is not found in Indonesian. The students are not aware of the use of possessive marker to show possession of a noun. Another frequent error made by the students is verbs changing. Tenses in English are important as its function is as a time signal. The students do not keep this rule in their minds. In this sentence Last holiday I go to Jakarta", we notice that the student should put simple past tense verb „went ${ }^{\text {ee }}$ instead of simple present ,go ${ }^{\text {ee }}$. It is even clearer to see that the student puts the adverb ,last holiday" which indicates past 
time. Here, the student completely doesn ${ }^{\text {ee }} \mathrm{t}$ understand the rule of tenses used in a recount text.

Besides mother tongue interference, errors can be caused by intralingual errors. Richards (1973: 6) argues that interlingual interference refers to items produced by the learner which reflect not the structure of the mother tongue, but overgeneralization based on partial exposure to the target language. Students sometimes do not fully

understand about target language structures. That is why they make errors based on their partial understanding of the target language structures. Based on Richards (1984: 74-177), he mentions that intralingual error consists of overgeneralization, ignorance of rule restrictions, incomplete application of rules and false concept hypothesized. Below are the explanations and examples of errors caused by:

1. Overgeneralization

This error happens when the learner creates a deviant structure on the basis of his experience of other structures in the target language (Richard, 1984: 174).The example of this cause of error is ,Last holiday, my family and I went go to Tawang Manguee.

2. Ignorance of restricted rules

This error happens when a learner fails to observe the restrictions of existing structures, that is, the application of rules to context where they do not apply (Richards, 1984: 175-176). The example of this cause of error is

\section{„Before we went to home, I and my}

brother bought ice tea

3. Incomplete Application of rules

This error occurs in the structure whose deviancy represents the degree of the rules required to produce acceptable utterances. This type of intralingual error happens if a learner fails to fully develop a structure (Richards, 1984: 177). The example of this cause of error is ,I went there *** my family"

4. False Concept Hypothesized

This error happens when a learner fails to comprehend the distinctions in the target language (1984: 178-181).The example of this cause of error is ,We left Solo at 08.30 am through Klaten town"

Errors made by the students are apparently a part of process of learning a second language. As supported by Dulay, Burt and Krashen (1982: 138), that people cannot learn language without first

systematically committing errors. Furthermore, Corder (1981: 10-11) points out some merits of error analysis which are (1) first to the teacher, in that they tell him, if he undertakes a systematic analysis, how far towards the goal the learner has progressed and, consequently, what remains for him to learn; (2) errors provide to the researchers evidence of how language is learned or acquired, what strategies or procedures the learner is employing in his discovery of the language; (and in a sense this is their most important aspect) errors are indispensible to the learner himself, because we can regard the making of errors as a device the learner uses in order to learn. Error analysis can be conducted in the students ${ }^{e e}$ production skill such as speaking and writing.

As a means of communication, language can be expressed both in spoken and written form. Unlike spoken, written language has to be learned consciously. Spoken language, for a child, is acquired 
naturally as a result of being exposed to it, whereas the ability to write has to be consciously learned (Harmer, 2004:3). To be able to communicate well, one has to master the English spoken language and written form. Here, the researcher is attempting to analyze the students ${ }^{\text {ee }}$ error in their writing of recount texts. A recount text is one of the text types which are taught to junior high school students.

\section{METHOD OF THE RESEARCH}

The researcher uses descriptive research to describe errors made by the eighth grade students of SMP Negeri in Surakarta. Nawani and martini (1994: 73) define descriptive method as a procedure to solve problem which is being investigated by describing the situation of the objects at the present time, based on the rising facts or as what they are in real life. The researcher uses purposive sampling as the sampling technique. The population of this research is the eighth grade students. The sample chosen by the researcher is class VIII A which consists of 24 students.

To collect the data, the researcher uses written test of recount text. The students are given a test to make a writing of recount text. After the data are collected, the researcher analyzes them by following some stages which are identifying the errors, describing the errors and explaining the errors. In describing the type of error, the researcher uses surface structure taxonomy proposed by Dulay, Burt, Krashen (1982:150). In analyzing the students $^{\text {ee }}$ errors, the researcher uses this formula to get the percentage of type of error. Here $\mathrm{s}$ the formula:

$E=P$

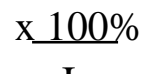

I

Explanation:

$\mathrm{E} \quad=$ Type of Error percentage

$\mathrm{P}=$ Number of Type of Error

I $=$ Total Number of Type of Error

While, to get the percentage of source of error, the researcher employ this formula:

$\mathrm{E}=\mathrm{P} \quad \mathrm{x} \underline{\mathrm{100} \%}$

Explanation:

$\mathrm{E} \quad=$ Source of Error percentage

$\mathrm{P}=$ Number of Source of Error

I= Total Number of Source of Error

\section{RESEARCH FINDINGS DISCUSSION FINDINGS}

AND

Table 1.The Frequency of Type of Error

\begin{tabular}{lcc}
\hline \multicolumn{1}{c}{ Types of Error } & Number & Percentage (\%) \\
\hline Addition Error & 38 & 14.34 \\
Omission Error & 79 & 29.81 \\
Misformation Error & 146 & 55.10 \\
Misordering Error & 2 & 0.75 \\
\hline \multicolumn{1}{c}{ Total } & $\mathbf{2 6 5}$ & $\mathbf{1 0 0}$ \\
\hline
\end{tabular}

Table 2. The Frequency of Source of Error

\begin{tabular}{lccc}
\hline \multicolumn{1}{c}{ Source of Error } & Number & Percentage (\%) \\
\hline Interlingual & 155 & 58.49 \\
Intralingual: & 110 & 41.51 \\
a. Overgeneralization & 9 & & \\
b. Ignorance of rule & 38 & & \\
\hline
\end{tabular}




\begin{tabular}{llll}
\hline c. & $\begin{array}{l}\text { restrictions } \\
\text { Incomplete application of } \\
\text { rules }\end{array}$ & 33 & \\
d. $\begin{array}{l}\text { False Concept } \\
\text { Hypothesized }\end{array}$ & 32 & \\
\hline \multicolumn{1}{c}{ Total } & $\mathbf{2 6 5}$ & $\mathbf{1 0 0}$ \\
\hline
\end{tabular}

\section{DISCUSSION}

The researcher analyzes 220 sentences obtained from the 24 students $^{\text {ee }}$ writing. There are 266 erroneous sentences which are classified as errors (265 errors) and one mistake found from the studentse writings. There are four types of error found from the students ${ }^{\text {ee }}$ writing. They are addition error, omission error, misformation error and misordering error. Each of the type of errors has many categories.

\section{Type of Error}

a. Addition Error

There are 38 or $14.34 \%$ of total errors which are categorized as addition error. This type of error has 7 categories. They are addition error of To Be (Copula Verb) (18.42\%), addition error of preposition $(60.54 \%)$, addition error of verb $(5.26 \%)$, addition error of possessive pronoun $(2.64 \%)$, addition error of conjunction (5.26\%), addition error of semicolon $(2.64 \%)$, addition error of adverb (2.64\%). The highest category of addition error is addition error of preposition with the percentage of 60.54. The students frequently make errors of preposition by adding an item which is not needed. The example of this case is ,In there I saw many animal". The student adds a preposition „in" beside another preposition ,there ${ }^{e e}$. The student fails to delete an item which should not appear in a well-formed sentence.

b. Omission Error
The students ${ }^{\text {ee }}$ writings contain 79 omission error or $29.81 \%$ of total errors. There are 12 categories of omission error. They are omission error of preposition (13.92\%), omission error of subject $(10.53 \%)$, omission error of inflection morpheme ,$-\mathrm{S}^{\mathrm{ee}}$ as possessive marker $(31.58 \%)$,

omission error of inflectional morpheme ,-s/es ${ }^{\text {ee }}$ as plural marker ( $7.60 \%$ ), omission error of determiner (7.60), omission error of verbs (11.40\%), omission error of To Be (Copula Verb) (13.92\%), omission error of pronoun (1.27), omission error of article $(18.99 \%)$, omission error of noun head $(1.27 \%)$, omission error of modal verbs (1.27) and omission error of conjunction (2.53). The highest omission error is omission error of inflection morpheme ,-se $\mathrm{S}^{\mathrm{ee}}$ as possessive marker with the percentage of $31.58 \%$. In this category, the students omit an item which is should appear in a wellformed sentence. In this sentence, ,I visited my grandmother* house", there is an absence of an item which is an inflectional morpheme,$-\mathrm{s}^{\text {ee }}$. The student should provide an inflectional morpheme,$-\mathrm{se}^{\text {ee }}$ beside the noun ,grandmother to show a possession.

c. Misformation Error

Misformation error is the most frequent types of error. Its percentage is $55.10 \%$ or 146 errors of total errors. This type of error consists of 11 categories of misformation error which 
cover misformation error of ordinal number $(0.68 \%)$, misformation error of past tense $(50.00 \%)$, misformation error of word choice (23.28\%), misformation error of word spelling $(3.42 \%)$, misformation error of preposition $(8.90 \%)$, misformation error of present tense (5.48\%), misformation error of present perfect tense $(0.68 \%)$, misformation error of past modal verbs $(1.37 \%)$, misformation error of subject $(1.37 \%)$, misformation error of present participle tense $(1.37 \%)$ and misformation error of adverb $(1.37 \%)$. The highest category of misformation error comes from misformation error of past tense. This fact is supported by the fact that tense brings many difficulties face by the students. Tense does not exist in Indonesian that is why many students frequently ignore the rule of tense of recount text. They do not change the verb into past tense. In this sentence „After that we continue the touring to Talangria beach" (21/2) have the verb in the form of present tense. The student doesn "et understand the rule that verbs in English have a function which is as time signal. It gives the reader an idea of when an action takes place. Moreover, here the student is given an assignment to make a composition about their past experience, and then the verb has to be in the form of past tense.

d. Misordering Error

From the studentse writing, there are only two sentences which contain misordering error. this type of error has two categories. They are misordering error of prepositional phrase and misordering error of adverb. One of those two categories is in this sentence „On the way to Talangria beach we enjoyed (20/1), the prepositional phrase ", on the way to Talangria" is the object of the verb ,enjoyed". The prepositional phrase itself contains errors as it is supposed to be written as „our way to Talangria", but here the writer is focusing only on the order of the sentence. The object of the sentence "on the way to Talangria" is better placed after the verb ,enjoyed".

The overall revision is ,We enjoyed out way to Talangria".

\section{Source of error}

Many errors yielded by the students are caused by interlingual error and intralingual error. Interlingual error gains $58.49 \%$ of the students ${ }^{\text {ee }}$ errors and intralingual error gains $41.51 \%$.

a. Interlingual error Many errors yielded by the students are caused by the application of the students ${ }^{\text {ee }}$ first language structures to the target language structures. Here are the errors caused by interlingual error:

\begin{tabular}{|c|c|c|}
\hline No & Type of Error & Error Example \\
\hline 1 & \multicolumn{2}{|c|}{ Addition Error of PrepositionIn there I saw my aunt, my uncle and my niece } \\
\hline 2 & $\begin{array}{l}\text { Omission Error of } \\
\text { grammatical Morpheme ,s as a } \\
\text { possessive marker }\end{array}$ & $\begin{array}{l}\text { Last night, I and my friend went to Risa* house } \\
(05 / 1)\end{array}$ \\
\hline 3 & $\begin{array}{l}\text { Omission Error of } \\
\text { grammatical morpheme }, \mathrm{s}^{\mathrm{ee}} \text { for } \\
\text { plural noun }\end{array}$ & In there, I saw many animal* $(12 / 1)$ \\
\hline 4 & \multicolumn{2}{|c|}{ Omission Error of article ,the ${ }^{e e}$ In $* * *$ third day I go to hotel $(07 / 9)$} \\
\hline
\end{tabular}




\begin{tabular}{|c|c|c|}
\hline 5 & Omission Error of To Be & In there the view $* * *$ very beautiful $(21 / 3)$ \\
\hline 6 & $\begin{array}{l}\text { Misformation Error of Past } \\
\text { Tense }\end{array}$ & Last holiday I $g o$ to Jakarta $(07 / 1)$ \\
\hline 7 & $\begin{array}{l}\text { Misformation Error of Pastl wa } \\
\text { Form of Modal verb ,willee }\end{array}$ & $\begin{array}{l}\text { very happy and sad because I' } \underline{l} \underline{l} \text { be go } \\
\text { home }(08 / 6)\end{array}$ \\
\hline 8 & $\begin{array}{l}\text { Omission Error of Determiner } \\
\text { for noun „house }\end{array}$ & $\begin{array}{l}\text { After that I and my sister and my brother } \\
\text { swimming near house }(15 / 5)\end{array}$ \\
\hline 9 & $\begin{array}{l}\text { Misformation Error of Word } \\
\text { Choice „washed my body }\end{array}$ & $\begin{array}{l}\text { In the afternoon, I went home and washed my } \\
\text { body }\end{array}$ \\
\hline
\end{tabular}

Here are some of the explanations of the data above:

1. In there I saw my aunt, my uncle and my niece (13/3)

The addition error of preposition of place , in ${ }^{\text {ee }}$ is caused by the student ${ }^{\text {ee }}$ s poor translation of Indonesian to English. The translation of the phrase is "disanae ${ }^{e e}$, therefore the student puts in as "die and there as ,sana ${ }^{\text {ee }}$. But, in English there itself means „disana“ So, the presence of ,in in the sentence is a reflection of the students ${ }^{\text {ee }}$ mother tongue interference.

2. Last night, I and my friend went to Risa* house(05/1)

Possession in English is marked by grammatical morpheme ,s (apostrophe ,s) as in ,My father" $s$ house" or by the use of preposition "of for an non-living thing as in ,the cover of the book". Possession in Indonesian is marked by the addition of suffix - ku, -mu, -nya. But in English, it is marked by the present of grammatical morpheme apostrophe "se. The students, in their writing, is rarely aware of the addition of apostrophe,s to show possession.

3. Last holiday I go to Jakarta (07/1)

Verbs in English have agreements with tense. In other words, the verbs give us the information about when activities happen. However, the students create many errors in their form of verb they use in recount text. They do not change the verb form of present tense to past tense. These errors are done repeatedly. This happens because the students use their Indonesian structure which has the assumption that the form of a verb remains the same form and the time signal for past activities can be explained by the use of adverb of time. The students use the adverb of time such as: yesterday, two days ago, last year, etc to denote the time signal without change the verb form to past tense from.

b. Intralingual

Intralingual error has the percentage of $41.51 \%$ of the total students ${ }^{\text {ee }}$ errors. The following are the examples of intralingual error found in the students ${ }^{\text {ee }}$ writing:

1. Overgeneralization

This sentence ,May 8 2014, I were help my parent in the morning (01/1) is categorized as overgeneralization error because the student involves his previous structure to a new situation. To be ,were" is not supposed to be appeared in that sentence. The student thinks that to be "were" is put right in the sentence since its form is past tense. Then he put another verb which is ",help". The verb of the sentence is ,help" but the error occurs in the presence of to be ,were

2. Ignorance of rule restrictions 
In this sentence „Before we went to home, I and my brother bought ice tea" the student uses his analogy of the use of preposition "to". He has understood his past experience as the verb "go " is always followed by preposition ,,to" as in ,I go to school". But, here the student doesn"t realize the strict rule that the preposition "to "is not needed in the sentence, went to home". He student has to write ,went home" instead of ", went to home". Here the student ignores a strict rule of using preposition "to" because he employs the analogy of his previous acquired strategy.

3. Incomplete application of rules

In this sentence, ,I went there $* * *$ my family "is incomplete because the student doesn"t include preposition ,with". The student has to include preposition ,with" to show a companion as he doesn "t $\mathrm{go}$ to a particular place alone.

4. False Concept Hypothesized

The verb „was " in this sentence „Her name wasDesi" is incorrect. The student doesn "t need to change the verb ,is" to its past form "was". Recount texts involve the use of simple past tense in its language feature. That is the studentes assumption that she writes "was" instead of ,is". But here, the name of the student"s niece "Desi" is a statement of fact. Therefore, the verb should not be changed to past form but it remains as based form , is".

\section{CONCLUSION AND SUGGESTIONS}

Based on the findings, it can be concluded that (1) there are four types of error found from the students; writing which include addition error, omission error, misformation error and misordering error; (2) there are two source of error which cover interlingual error (58.49\%) and intralingua error with the percentage of $(41.51 \%)$; (3) the highest frequency of type of error is misformation error with the percentage of $55.10 \%$ and the most frequent source of error is interlingual error which occurs in 146 errors (58.49\%).

The data above show that the students still encounter difficulties in learning English especially in writing recount text. Regarding that more source of errors are caused by interlingual error than intralingual error, it can be implied that the students are accustomed to using their mother tongue knowledge to replace their limited knowledge of the target language.

According to the analysis, the researcher gives some suggestion which are (1) in teaching English, the teacher should explain clearly about the rules of the structure as it can be seen that the students are still confused about the structures especially the structures used in the recount text; (2) regarding that the students frequently make errors dealing with tense especially past tense, the teacher should provide more exercises dealing how to provide the correct form of past tense and when to use it; (3) the teacher should build the awareness of the differences between mother tongue structures and the target language structures since it is found that interligual error named as the most influencing errors found from the students" writings; (4) the teacher should give remedial teaching if it is necessary (5) for the students, they have to be aware of the influence of their mother tongue structure to English structure since they sometimes use their mother tongue structure in replace of the English structure that they do not understand. 


\section{BIBLIOGRAPHY}

Anderson, Gary. \&Arsenault, N. 1998.

Fundamentals ofEducational

Research. Pennsylvania: The Falmer Press

Corder, S. Pit. 1981. Error Analysis and

Interlanguage. Oxford: Oxford University Press

Dulay, Heidi C. 1982. Language Two. Oxford: Oxford University Press
Harmer, Jeremy. 2004. How to Teach Writing. Longman.

Nawawi, H \& Martini, M. 1994. Penelitian Teerapan. Yogyakarta: Gajah Mada University

Norrish, John. 1983. Language Learners andTheirErrors. London: Macmillan Publishers Ltd.

Richards, J.C. (ed). 1973. Error Analysis. London: Longman. 